\title{
ARE WE THERE YET? - EXPLORING ON-THE-JOB TRAINING OF THE PHILIPPINE PRE-SERVICE BIOLOGY STUDENTS
}

\author{
Eden V. Evangelista*, Marie Paz E. Morales** \\ * Philippine Normal University, College of Graduate Studies and Teacher \\ Education Research, Taft Avenue, Philippine \\ E-mail: evangelista.ev@pnu.edu.ph \\ ** Philippine Normal University, Educational Policy Research and \\ Development Center, Taft Avenue, Philippines \\ E-mail: mailto:morales.mpe@pnu.edu.ph
}

\begin{abstract}
Critical assessment using Context-Input-Process-Product (CIPP) model of the research- and laboratory-based on-the-job training (OJT) program of pre-service biology teacher highlights this study. Researcher-made instrument anchored on CIPP checklist and interview protocols deduced pertinent data from the third year pre-service biology teachers in two consecutive years. Results show that OJT students assessed the OJT program as 'effective' in the aspects of context and input. Furthermore, they evaluated the process and product of the OJT program as 'very effective'. Overall, a significant difference occurred in the program assessment rating of the OJT students for the two consecutive years, in favor of the most recent year as an improved OJT program. All the aspects of the CIPP model significantly change for better assessment in the recent year except for the product construct. Qualitatively, verbal comments and interview responses of the participants provided good qualities of the OJT program that needs to be sustained for better implementation of theory-practice framework. OJT students' negatively stated verbal comments, however, provided inputs for enhancement of the OJT program in order to help pre-service education train for scientifically literate students to ultimately reach the goal of sustainable development and lifelong learning of Filipino learners.
\end{abstract}

Key words: On-the-job training, pre-service, practicum, CIPP model, biology students 


\section{Introduction}

UNESCO (2014) confirms that education is a fundamental human right that brings a wide variety of benefits and creates opportunities both directly and indirectly. It also equips, and hence empowers, people with the knowledge and skills they need for better, more dignified lives. But what's next after UNESCO's overarching goal of achieving Education for ALL (EFA) by the year 2015? This global education movement brings the world to an era where country boundaries are being crossed through trade, commerce $\&$ investments; mode of communication, mobility of students, teachers \& other professionals; and environmental ideologies \& concerns. Thus, UNESCO's post-2015 agenda framework blends Millennium Development Goal (MDG) 2 on "Universal access to Primary Education" with EFA goals and endorse a general goal- "Ensure equitable, quality education and lifelong learning for ALL by 2030" to achieve just, inclusive, peaceful and sustainable societies. Decoded into specific global targets to which countries would commit and held accountable, quality education and relevant teaching and learning are some of the post-2015 agenda's priority areas. Good-quality education is the process of equipping people with the skills, knowledge and attitudes to: obtain decent work; live together as active citizens nationally and globally; understand and prepare for a world in which environmental degradation and climate change present a threat to sustainable living and livelihoods; and understand their rights. Hence, UNESCO (2014) highlights the teachers' central role in ensuring good-quality education and learning.

For education to be considered as the most important enabling instruments, providing the only path towards a virtuous cycle of equal opportunity, fair competition and just rewards, quality must be emphasized and attained. Thus, there is a need for quality assurance in this field of knowledge. Quality assurance, according to Church (1988) is not about specifying the standards or specifications against which to measure or control quality. Quality assurance is about ensuring that there are mechanisms, procedures and processes in place to ensure that the desired quality, however defined and measured, is delivered. Furthermore, the UNESCO Regional Report of Asia and the Pacific describes quality assurance in higher education as the systematic management and assessment procedures to monitor performance of higher education institutions. Quality, considers all aspects of education-from teaching and academic study programmes, research and scholarship, staffing, students, infrastructure and facilities, services to the community and the academic environment. Thus, internal self-evaluation and external review, conducted openly by independent specialists, if possible with international expertise, are vital for enhancing quality. 
In 2003, the ASEAN Economic Community (AEC) established regional initiatives for quality assurance with core elements that included free flow of services and free flow of skilled labour. The blueprint mandated the ASEAN Universities Network (AUN) to boost cooperation among member universities and enable the mobility of both students and staff within the region. At the core of the mutual recognition agreements (MRAs), students and staff mobility in the region is quality assurance (QA). This goal expected to ensure that educational standards are harmonized and benchmarked among universities in the region. Additionally, UNESCO also emphasized that "quality assurance is linked to professional mobility, and a growing number of regional and international integration processes. In the AUN context, quality assurance takes into consideration accountability that is related to processes-i.e., whether minimum standards are in place, and development that is related to academic developmental goals anchored on its strengths and weaknesses. Accordingly, both accountability and development are evaluated internally. Internal QA (IQA) guarantees that an institution, system or study programme has policies and mechanisms in place to make sure that it is meeting its own objectives and standards. It centres on the quality of inputs, processes and output that checks the presence of mechanisms that control and ensure the level of quality in higher education.

In the Philippines, efforts to attune the country to the regional and global contour led to the establishment of the Philippine Qualification Framework (PQF, 2012). Objectives of this framework include 1) to adopt national standards and level for outcomes of education; 2) to support the development and maintenance of pathways and equivalencies which provide access to qualifications and assist people to move easily and readily between the different education and training sectors and between these sectors and the labour market; and 3) to align the PQF with international qualifications framework to support the national and international mobility of workers through increased recognition of the value and comparability of Philippine qualification. With PQF, all education sectors are tasked to make detailed descriptors for each qualification level based on learning standards in basic education, competency standards of training regulations, and the policies and standards of higher education academic programs. Guided by the vision, mission and goals of PQF, Philippine higher education system is mandated to contribute to building a quality nation capable of transcending the social, political, economic, cultural and ethical issues that constrain the country's human development, productivity and global competitiveness. Specifically, Philippine universities and colleges are tasked to produce graduates with high levels of academic, thinking, behavioural, and technical 
skills/competencies that are aligned with national academic and industry standards and needs and international standards, when applicable.

As aforementioned, evaluation schemes and means direct the quest for quality outcomes of higher institution graduates. Academic institutions are putting much effort to produce graduates that match the needs of the industry. Job-skill matching is reinforced through on-thejob training programs. Department of Labor and Employment (DOLE, 2006) defined on-thejob training (OJT) programs as course requirements providing an opportunity to apply the theories, principles and ideas learned in the academe under supervision. OJT's let the students experience work realities which will ideally refine their skills and prepare them to the world of work. People Management Association of the Philippines (PMAP) in 2006 emphasized the importance of an effective on-the-job training program to ensure appropriately skilled graduates. Hence, universities and colleges collaborate with national government agencies and private institutions for skill-specific tasks and mentoring.

In education, teachers play significant roles to the success of educational reform (Darling-Hammond and Berry, 1998). Qualified and skilled teachers are not only agents of positive societal change but also have a multiplying effect touching the lives and molding the hearts of learners. Hence, the academe seeks for good quality teacher preparation. Teacher education programs aim to develop the knowledge, skills and attributes of pre-service teachers' in order to prepare them to teach effectively in twenty first century classrooms. Shulman (1986b) acknowledged that teaching combines artistic and scientific processes and skills. Knowing what to teach, how to teach it, and what methods to use with specific topics, certain kinds of students and in particular settings all combine to form the knowledge and skills that define teaching expertise. Thus, the effective mentoring and practice are vital in teacher preparation.

\section{The Concept of Practice}

Practice connects with 'practical reasoning', using knowledge in the face of uncertainty, understanding that action is a kind of exploration of what might possibly be done, and understanding that the historical consequences of practice in a particular case will only become apparent in the future (Kemmis, 2009). Furthermore, Kemmis (2009), Carr (2009) and other representatives of a neo-Aristotelian approach argue that practical reasoning is a constructive way to research professional practice. This practical nature of pre-service education training program roots from Dewey's theory of experience. Shon (1996) extended Dewey's model by 
directing theory of experience to reflective practice in the learning process. With these theories, Universities designed pre-service education to focus on both content and practice or 'practicum'. In a practicum course, the pre-service teacher is placed within a school setting (either elementary or senior) and models an experienced teacher. The pre-service teacher will be given opportunities to develop skills through observing their associate teacher, creating lesson plans, teaching lessons and experiential learning about classroom management.

\section{Models for Practicum}

Different universities and teacher education institutions model practicum course. Practicum in teacher education is dealt with in different ways at different universities. Different models emphasize different ideas, aspects and qualities. Historically, practicum roots from different points of views and they represent different views on how professional practice knowledge is best nurtured (Eilertsen \& Strøm, 2008; Eraut, 1994/2006; Haugaløkken \& Ramberg, 2005; Kvale, 2000; Lave \&Wenger, 1991; Lindström, 2008; Mattsson, 2008a; Mattsson 2008b, Ponte, 2007; Vande Ven, 2011; Wenger, McDermott \& Snyder, 2002). Some of these models are described as follows by Mattsson, Eilertsen and Rorrison (Eds) (2011):

- Master-Apprentice model. The model exemplifies a novice learning the profession from somebody who masters the profession. The master and his colleagues are expected to know the practice knowledge that is worth knowing and developing. They know the tradition.

- Laboratory model (övningsskola). In this model, Universities with training schools offer pre-service teachers practicum course in a good educational environment by excellent professional teachers.

- Partnership model showcase collaboration between a university and local schools that have been carefully selected. Local mentors/supervisors are appointed for pre-service teachers. They are expected to offer a good educational environment.

- Community development model is often applied in rural settings where pre-service teachers during practicum should bring new ideas and methods to schools and teachers in need of improving their pedagogical standard.

- Integrated model is practiced by universities and communities who have agreed to share responsibility for a teacher education where practicum serves as an integrative element. The model is based on the idea that pre-service teachers should learn from a variety of schools and teachers that may differ a lot in quality. 
- Case based model. The model typifies an educational practice inspired by the practical wisdom of medicine, should encounter a large number of authentic cases in order to learn how to identify resemblances and distinctive traits. They should learn how to analyse and interpret cases in the light of research, theory and experience.

- Platform model symbolises a framework of teacher education that is more flexible and open to pre-service teachers' individual needs and interests. The model offers opportunities for pre-service teachers' participation in projects that exceed the traditional practicum periods and provide closer and more versatile links between universities and schools.

- Community of practice model is based on the idea that learning is part of a social praxis where participants learn from each other. Pre-service teachers are socialised into a culture of inquiry.

- Research and Development model. This model is characterized by agreements between universities and communities about how to collaborate in order to improve relevant research as well as school development.

In the Philippine context, practicum programs are termed as 'experiential learning courses' (ELCs). As mandated (Commission of Higher Education - CHED Memorandum Order No. 30, s.2004), ELCs are indispensable components of the new teacher education curriculum. Accordingly, the practicum program is pursuant to the National Competency Based Teacher Standards (NCBTS) which is the identified core of the teacher development program (TEDP) of the government. Furthermore, ELC's are intended to provide students with actual learning experiences in which they can observe, verify, reflect on, and practice the different components of the teaching - learning processes in a variety of authentic school settings. Mentoring practices build from field observations and will gradually intensify into participation then actual classroom immersion as practice teacher or student teacher. This model permeates in almost all teacher education institutions in the country. However, as CHED moves towards locally responsive but globally attuned state, quality teachers are vital outcomes of teacher education curricula. This quest directs all academe efforts to design teacher curricular program and evaluates these programs to ensure success in training quality teachers.

\section{Context-Input-Process-Product (CIPP) Evaluation Model}

Stufflebeam (2007) introduced the CIPP Evaluation Model as a comprehensive framework for guiding evaluations of programs, projects, personnel, products, institutions, and systems. 
Formally, Stufflebeam (2007) defines evaluation as the process of delineating, obtaining, providing, and applying descriptive and judgemental information about the merit and worth of some object's goals, design, implementation and outcomes to guide improvement decisions, provide accountability reports, perform institutionalization/dissemination decisions, and improved understanding of the involved phenomena. Accordingly, the description theorises four commitments of evaluation: guiding decisions, providing records or accountability, informing decisions about installing and/or disseminating developed products, programs, and services; and promoting understating of the dynamics of the examined phenomena.

Correspondingly, CIPP's core concepts are context, input, process, and product evaluation. Context evaluation determines the needs, problems, and opportunities within a defined environment. Input evaluation assesses competing strategies, work plans and budget approaches. This process helps users to design improvement efforts, device defensible feasible funding proposals and details plans of action. Process evaluation observers, monitors, documents and gauge activities. This component helps uses implement improvement efforts. Finally, product evaluation identify and assess and record their level of success in reaching and meeting the beneficiaries' targeted needs; identify intended and unintended side effects; and make informed decisions to continue, stop, or improve the effort.

The CIPP Model represents a holistic approach to conducting evaluations of education, health and other public programs. CIPP stands for: Context evaluation, Input evaluation, Process evaluation, Product evaluation

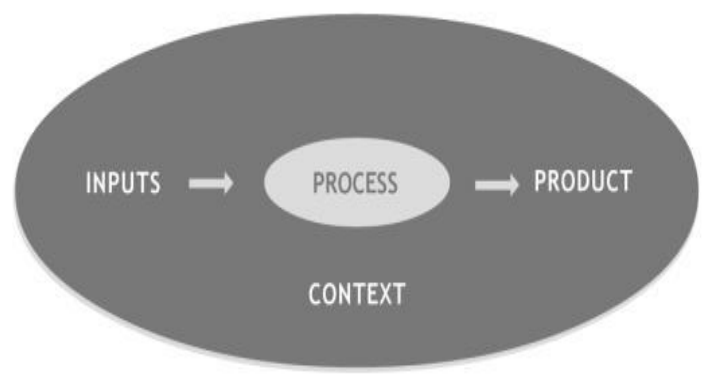

Figure 1. CIPP Model by Stufflebeam

Context evaluation includes examining and describing the following:

- program context - the values, goals and objectives of the training program.

- target population and its needs - defines the skills, both actual and desired that the students need.

- opportunities for addressing needs - defines the environment for addressing the needs. 
- problems underlying the needs - diagnose problems and barriers in achieving the needs.

- whether program goals are sufficiently responsive to the assessed needs Input evaluation includes activities such as a:

- description of the program inputs and resources

- comparison of how the program might perform compared to other programs

- evaluation of the proposed design of the program

- examination of what alternative strategies and procedures for the program should be considered and recommended strategies/ it can help the decision makers to choose the best OJT strategies

Process evaluation includes:

- examining how a program is being implemented

- monitoring how the program is performing

- auditing the program to make sure it is following required legal and ethical guidelines

- identifying defects in the procedural design or in the implementation of program Product evaluation includes:

- determining and examining the general and specific outcomes of the program (i.e., which requires using impact or outcome assessment techniques)

- measuring anticipated outcomes

- assessing the merit of the program - should it be continued or not?

- conducting a retrospective benefit/cost assessment (to establish the actual worth or value of the program).

In response to UNESCO's call for quality teachers, the government delegated the National Center for Teacher Education - Philippine Normal University to offer quality preservice education. In all its curricular offerings, practicum is a vital course. Specifically, the Bachelor of Science in Biology for Teachers (BSBT), practicum comes in two forms: practice teaching and on-the-job training. A Memorandum of Agreements (MOA) with several research institutions in Metro Manila was instituted in 2006 to help in training biology students. Institution and agency list included: the Philippine National Museum (PNM), Philippine Nuclear Institute (PNRI), Bureau of Fisheries and Aquatic Resources (BFAR) and The Rizal Technological University (RTU). These research institutions have been the arm of PNU in conducting the "On-the Job Training" (OJT) of BS in Biology for Teachers students for the past 
years. However, whether the practicum program is beneficial to both students and the government is the purpose of this study. Evaluation of the aforementioned program hopes to provide (a substantial amount of) important data that will give valuable suggestions for future management decisions and would attune the program to the Outcome-Based Education (OBE) directions of higher education.

\section{Purposes of the Research Study}

This study aims to evaluate the effectiveness of the Bachelor of Science in Biology for Teachers (BSBT) OJT program and assess if it is able to produce quality and skilful students as intended. Specifically, the study sought to realize the following objectives:

1. Describe the overall evaluation of the BSBT students regarding the OJT Program in the following aspects:

1.1. context of the program;

1.2. inputs incorporated in the program;

1.3. processes by which the program was implemented;

1.4. products as outcome of the program.

2. Statistically compare the current students' satisfaction level with that of the previous year.

\section{Methodology}

Descriptive normative research method gathered pertinent data in this study. Survey design was conducted to 38 Bachelor of Science in Biology for Teachers (BSBT) graduating students of the Philippine Normal University, SY 2012-2013 and 61 BSBT graduating students of SY 2013-2014 who took OJT programs. A researcher-made survey questionnaire based on the CIPP evaluation checklist collected data on self-evaluation of students with regards the OJT program. Interview responses collected support data to the survey results. Survey results were gathered and statistically analysed to determine self-evaluation rating of the OJT students on OJT programs and the significant difference between the self-rating of the two recent batches of OJT students in Biology.

\section{Results and Discussion}

The study underscored the self-evaluation of the Biology student of their OJT program in two consecutive school years. The succeeding tables present the overall evaluation of the students.

Table 1. Biology Student Evaluation of the Context of OJT Program for two consecutive school years 


\begin{tabular}{|c|c|c|c|c|}
\hline \multirow{2}{*}{ Context of the Program } & \multicolumn{2}{|c|}{ Year 1} & \multicolumn{2}{|c|}{ Year 2} \\
\hline & Mean & Interpretation & Mean & Interpretation \\
\hline $\begin{array}{l}\text { The program offering is relevant to the future job you } \\
\text { might be employed in. }\end{array}$ & 3.24 & Effective & 3.49 & Effective \\
\hline $\begin{array}{l}\text { The program provides adequate time for you to learn } \\
\text { competencies or skills necessary to be able to adapt in the } \\
\text { fieldwork. }\end{array}$ & 3.34 & Effective & 3.22 & Effective \\
\hline $\begin{array}{l}\text { The program is helpful and useful in building your future } \\
\text { career. }\end{array}$ & 3.47 & Effective & 3.45 & Effective \\
\hline $\begin{array}{l}\text { The job exposure given is fitting to the course you have } \\
\text { taken. }\end{array}$ & 3.47 & Effective & 3.48 & Effective \\
\hline $\begin{array}{l}\text { The goals of the program are achieved in the entire } \\
\text { duration of your On-the Job training. }\end{array}$ & 3.47 & Effective & 3.35 & Effective \\
\hline General Average & 3.40 & Effective & 3.35 & Effective \\
\hline
\end{tabular}

On program context, participants rated the OJT program with an average of 3.40 and 3.35 out of the maximum 4.0 in the Likert scale. Qualitative interpretations of these ratings underscore effective level of the OJT program to the Biology education curriculum and to the expected field work of students after they finish the degree. Furthermore, the students find the program relevant, even if they will pursue other non-teaching careers. As pre-service teachers, they see the relevance and effectiveness of the program to their future profession.

Equally, verbal comments and interview responses of these participants support the quantitative ratings provided for context of the program as presented below:

- Our OJT at National Museum provides as skills we can do when we graduate.

- The place or venue is good and appropriate for the trainees.

- The OJT program provides time for thinking about research topic.

- The training program is suitable for application of theories.

- The OJT program serves as an eye-opener for the marine biodiversity awareness.

- It helps us apply what we learn in school.

- Practice techniques and strategies that I haven't encountered in school.

- NFBC is a place where we can practice some of our duties as a professional.

- I learned a lot in RTU. Those techniques that we haven't experienced in PNU were introduced to us in Rizal Technological University (RTU).

- The skills and new techniques are inculcated deeply to the trainees. 
- The centre provides a chance for the trainee to apply all the learning they had in the classroom.

- The OJT program we had is something relevant and I think will be useful for us biology students.

- Seminars held are very appropriate for the course of the OJT students.

The OJT program for most of the participants is a venue where they can apply the theories they have learned in the University. From their verbal comments and interview responses, the University and the collaborating agencies were successful in bringing in a perfect blend of theory and practice. This alliance matches Rorrison's (2011) guiding practicum learning principle 2: Collaborative relationships between schools and university schools of education should be underpinned by a shared understanding of how theory and practice intersect to inform pre-service teachers about engaging pupils in quality learning that will prepare them for a future of change, challenge and lifelong learning also known as collaborative relationships. Furthermore, students' verbal remarks matched Rorrison's guiding practicum learning principle 1: Productive and transformative pedagogies linked to transparent and robust theories of learning should be clearly constructed, and the related teaching experiences carefully scaffolded, for pre-service teacher learning during the practicum also known as theories of learning.

In the area of 'input to OJT program,' Table 2 presents the entire evaluation done by the participants. Input refers to theories and concepts provided in the training, training venues, and situations appropriate to the students.

Table 2. Biology Student Evaluation of the Input of OJT Program for two consecutive school years

\begin{tabular}{|c|c|c|c|c|}
\hline \multirow{2}{*}{ Input of the Program } & \multicolumn{2}{|c|}{ Year 1} & \multicolumn{2}{|c|}{ Year 2} \\
\hline & Mean & Interpretation & Mean & Interpretation \\
\hline $\begin{array}{l}\text { The entry year ( } 3 r d \text { year level) for the OJT program is } \\
\text { appropriate to the kind of exposure you have had. }\end{array}$ & 3.45 & Effective & 3.56 & Very Effective \\
\hline $\begin{array}{l}\text { The theories and the concepts you have learned in the class are } \\
\text { most helpful for you to cope in the training field. }\end{array}$ & 3.13 & Effective & 3.27 & Effective \\
\hline $\begin{array}{l}\text { There are enough venues in the training field that provided } \\
\text { opportunity to learn beyond what was given in the university. }\end{array}$ & 3.32 & Effective & 3.49 & Effective \\
\hline
\end{tabular}




\begin{tabular}{|c|c|c|c|c|}
\hline $\begin{array}{l}\text { The situations encountered in the training field are helpful in } \\
\text { preparing you, once in the real world. }\end{array}$ & 3.29 & Effective & 3.54 & Very Effective \\
\hline $\begin{array}{l}\text { The OJT venue you were assigned is appropriate for you to } \\
\text { learn and be better equipped after graduation. }\end{array}$ & 3.34 & Effective & 3.46 & Effective \\
\hline General Average & 3.31 & Effective & 3.47 & Effective \\
\hline
\end{tabular}

Based from Table 2, the participants rated the OJT program with an average of 3.31 and 3.47 out of the maximum 4.0 in the Likert scale. Qualitative interpretations of these ratings accentuate 'effective level' of the OJT program to the Biology education curriculum and to the expected field work of students after they finish the degree in the input component. Student participants gave high ratings equivalent to 'very effective level' appropriateness of the year level for OJT program and situations encountered in the training field are helpful in preparing the pre-service biology teachers, once in the real world. Verbal comments presented student suggestions with regards better laboratory in the University. As a state funded institution, the Philippine Normal University only provides sufficient but not sophisticated and best laboratory tools, equipment and room. Instead of seeing completely that the theories and concepts learned in the class helped them excellently to cope in the training field, the deficient laboratory exposure in the university made them give a lesser rating. Students deployed in the OJT program who are exposed to sophisticated facilities and equipment seem to feel the inadequacy of content knowledge and skills thus, they view their pre-service university training in terms of input as just 'effective' and not 'very effective' in all constructs of input to the program. On a positive note, they assessed the laboratory exposures in the field as complementary and supplementary to what the University provided them. Verbal comments and interview responses complementing the aforementioned results are presented below:

- Each mentor and trainer enthusiastically approaches and handle the mentees in each activity.

- The people treat us as their very own family and friends and reach their aims up high in welcoming us.

- I learned a lot in RTU. Those techniques that we haven't experienced in PNU were introduced to us in RTU.

- The people of National Museum welcomed us very warmly and we felt we belonged.

- The program prepared for the trainees is very well organized and executed very well.

- The supervisors are friendly and approachable.

- Head supervisors are very kind. 
- Facilities are good.

- OJT Program is good for 3rd year Students.

- The place or venue is good and appropriate for the trainees.

- The OJT program serves as an eye-opener for the marine biodiversity awareness

- NFBC is a place where we can practice some of our duties as a professional.

- BFAR-NFRDI-NFBC has very good staffs that will assist trainees religiously during the course of the program.

Though students mentioned positive effects and benefits of the OJT program in their preparation as pre-service Biology teacher, there were also other verbal comments that can provide inputs to higher education curriculum designers. These comments were somewhat negatively stated, but can be identified as suggestions for improvement of the OJT program as presented below:

- Some tasks are very labour-intensive.

- Companies/institutions should be offering different opportunities like lab works, lecture, field works, and experiments.

- The students should be more involved in the activities under the programs of the institutions.

- Give the students the chance to actually handle equipment/machinery.

- There must be efficient and adequate tools in every activity.

- Students should be deployed in laboratories or research institutes for them to learn the lab techniques that are not done in school due to lack of equipment

- I suggest that the student/trainee at BFAR-NFRDI Batangas should go with the company personnel during water sampling in Taal Lake.

- Giving us opportunity to be involved in a workplace and exposing us to different people helped us developed our skills.

- Lack of supervision specifically in zoology division.

- I suggest to have a short lecture regarding plants on herbarium for us to refresh and gain more knowledge.

- Facilitators and complete instructions are needed in every training in OJT. They should have a good instructor to accomplish the given task.

- We should have been exposed to field more and should have given tasks that is more technical/ or suited on our level 
- I suggest that the affiliated company could also provide us more practical skills.

- The university should have more and appropriate equipment.

- I suggest that it should be more hands on training.

From the verbal comments, there is a need for better collaboration between the University and the partner agencies. Perhaps better protocols and agreement should be established. This agreement may include better staffing for OJT programs, specified agreed terms of reference of both parties, and intensive orientation of staff from both parties including the OJT students. Based on these, processes of OJT programs are vital to achieve the program's goals. Table 3 provides the student evaluation in the aspect of 'process of the program'.

Table 3. Biology Student Evaluation of the Input of OJT Program for two consecutive school years

\begin{tabular}{|c|c|c|c|c|}
\hline \multirow{2}{*}{ Process of the Program } & \multicolumn{2}{|r|}{ Year 1} & \multicolumn{2}{|r|}{ Year 2} \\
\hline & Mean & Interpretation & Mean & Interpretation \\
\hline $\begin{array}{l}\text { There was an orientation given by the department prior to the } \\
\text { deployment in the field. }\end{array}$ & 3.32 & Effective & 3.56 & Very Effective \\
\hline $\begin{array}{l}\text { There was proper endorsement to the partner institution/agency } \\
\text { before you started the OJT. }\end{array}$ & 3.08 & Effective & 3.58 & Very Effective \\
\hline $\begin{array}{l}\text { Visitation and monitoring is done by your OJT supervisor (faculty } \\
\text { from DBS) in the field. }\end{array}$ & 2.42 & $\begin{array}{l}\text { Moderately } \\
\text { Effective }\end{array}$ & 3.24 & Effective \\
\hline $\begin{array}{l}\text { Documented assessment of your training that was discussed and } \\
\text { processed in your presence (institutional supervisor). }\end{array}$ & 3.24 & Effective & 3.42 & Effective \\
\hline $\begin{array}{l}\text { Submission of a training portfolio / journal of your } \\
\text { accomplishments and learning while on the OJT is required. }\end{array}$ & 3.68 & Very Effective & 3.74 & Very Effective \\
\hline General Average & 3.15 & Effective & 3.51 & Very Effective \\
\hline
\end{tabular}

On program process, participants rated the OJT program with an average of 3.15 and 3.51 out of the maximum 4.0 in the Likert scale. Qualitative interpretations of these ratings range from 'moderately effective to very effective level' of the OJT program to the Biology education curriculum and to the expected field work of students after they finish the degree. Furthermore, OJT students observed proper process before, during and after the conduct of the OJT program. OJT students, however, assessed supervisor visitation and monitoring with 'moderately effective' rating. This implies that better terms must be provided to OJT supervisors and instructors for them to religiously conduct visitations and regular monitoring of students in OJT programs. Relative to the verbal comments in the input to the program, refinement of processes in the OJT program is called for by the students as presented below:

- The center should provide lecture / orientation for us to have background before the hands-on proper. 
- Thorough guidelines (and guide questions/forms) should be given to the trainees prior to the start of OJT. This may help in proper assessment and organization of learning experiences while the trainees are in the field.

- Before letting the trainees meet their partner-institution, the department should introduce the collaborating agency first to us or have some kind background information regarding the company.

- The OJT program must have a better orientation for the trainees so that he/she will know the situation encountered by the trainees.

The aforementioned verbal comments highlight the need to revisit and refine the protocols and processes in orienting all personnel for OJT programs including the students. Aside from orientation process and protocols, verbal comments which may serve as inputs to enhance OJT program in the areas of supervision and choice of institutions are presented below:

- On supervision

- OJT supervisors should visit the trainees for observation of their works/behaviour during working hours as well as to determine if there were some problems being encountered by the trainees.

○ The department must check the duties, provided by the company

- I suggest that a dedicated personnel to should be assigned to attend to the OJT.

○ More supervising visits by OJT supervisors.

- We were not that physically monitored by teachers/advisers from the university, but putting in understanding that the venue is really far, its fine.

- On the Choice of Institution

- Include other companies as OJT partners.

- Schools/Universities like UP, UST and others are place in good departments and are given seminars training related to their field.

- I hope that the time given to us for the OJT is longer.

- I suggest that it may be better if each OJT trainee will be training in at least 2-3 companies/institutions to provide a more varied experienced.

- The designation of places where we will be assigned should be done fairly. For those assigned in Batangas, we are only 5 and the other sections have.

Despite several alternative comments and interview responses, students of the OJT program recognize the importance of OJT program in pre-service education. Table 4 presents the student evaluation of the OJT program in the area of product of the program. 
Table 4. Biology Student Evaluation of the Product of the OJT Program for two consecutive school years

\begin{tabular}{|c|c|c|c|c|}
\hline Product of the Program & & Year 1 & & Year 2 \\
\hline After the OJT, I... & Mean & Interpretation & Mean & Interpretation \\
\hline $\begin{array}{l}\text { have become more confident to pursue a job after } \\
\text { graduation. }\end{array}$ & 3.47 & Effective & 3.63 & Very Effective \\
\hline $\begin{array}{l}\text { better appreciate the course because it is very relevant in } \\
\text { the training. }\end{array}$ & 3.57 & $\begin{array}{l}\text { Very } \\
\text { Effective }\end{array}$ & 3.70 & Very Effective \\
\hline $\begin{array}{l}\text { realized that the time spent in the field is worth the skills } \\
\text { and training gained. }\end{array}$ & 3.58 & $\begin{array}{l}\text { Very } \\
\text { Effective }\end{array}$ & 3.67 & Very Effective \\
\hline $\begin{array}{l}\text { see a promising future ahead because job opportunities } \\
\text { are met. }\end{array}$ & 3.46 & Effective & 3.93 & Very Effective \\
\hline $\begin{array}{l}\text { value the importance of OJT Program in preparing } \\
\text { graduates for the future. }\end{array}$ & 3.54 & $\begin{array}{l}\text { Very } \\
\text { Effective }\end{array}$ & 3.70 & Very Effective \\
\hline General Average & 3.52 & $\begin{array}{c}\text { Very } \\
\text { Effective }\end{array}$ & 3.72 & Very Effective \\
\hline
\end{tabular}

On the product of the program, the participants rated the OJT program with an average of 3.52 and 3.72 out of the maximum 4.0 in the Likert scale. These averages are quite high as compared to the averages in the other constructs. Qualitatively, these ratings are interpreted as 'very effective', thus, students believe that the OJT program is vital to Biology education curriculum in crafting better, more engaged and good quality biology teachers. Furthermore, OJT students gave very high ratings to a vision of a good future in terms of job opportunities through the OJT program. The views of the OJT students with regards how helpful OJT programs are in their future match the principles advocated by Worldwidelearn (2015). Accordingly, the group described internships as round out your work experience and develops students into highly attractive candidate for jobs after graduation. Interns work side-by-side with professionals on real projects and products. An increasing number of hiring officers prefer to hire job seekers who have completed internships in their industry. This way, they can guarantee that newly hired are familiar with the business environment. Moreover, in other specialized profession, apprenticeships are favoured for training. Students must complete an apprenticeship under the direction of a skilled supervisor before they can earn a license or a certification in their field. Traditionally, most apprenticeships begin immediately after a student earns their degree.

In sum, averages of each construct are provided in Table 5. Statistical comparison of the means in each of the constructs presents significant changes in the two consecutive years of evaluation. 
Table 5. T-test of the CIPP constructs

\begin{tabular}{cccccc}
\hline \multirow{2}{*}{ Aspects of Assessment } & \multicolumn{2}{c}{ Mean } & \multirow{2}{*}{ Std. Deviation } & \multirow{2}{*}{ p-value } \\
\cline { 2 - 3 } & Year 1 & Year 2 & & \\
\hline Context & 3.40 & 3.35 & 0.104 & $0.045^{*}$ \\
Input & 3.31 & 3.47 & 0.025 & $0.003^{*}$ \\
Process & 3.15 & 3.51 & 0.135 & 0.057 \\
Product & 3.52 & 3.72 & 0.152 & $0.042^{*}$ \\
\hline Overall & 3.34 & 3.51 & 0.168 & $0.025^{*}$ \\
\hline${ }^{*}$ Significant at $p<0.05$ & & & &
\end{tabular}

Comparatively, significant differences $(\mathrm{p}=0.045,0.003,0.042<0.05)$ in terms of context, input and product of the OJT program is perceived by students in year 1 and in year 2 . No significant difference $(\mathrm{p}=0.057>0.05)$ in years 1 and 2 in the construct 'process' was observed in the aforementioned data. Thus, OJT students in different years percieve the program differently except in the 'process' aspect. This result implies that improvement of the program was instituted in almost all aspects. This also means that sustained progress and enhancement of the OJT program is vital in the pre-service education of Biology student in the Philippines.

\section{Conclusion and Recommendation}

Generally, practicum is part of a particular educational system. It may be integrated into teacher education to greater or lesser extent. Grand Canyon University (2013) claims that practicum/field experience is an opportunity for teacher candidates to observe and participate in diverse educational settings, and to apply the theories and concepts learned in program course work. Accordingly, Schulz (2005) acknowledged that the traditional approach to practicum emphasize technical knowledge which is a small part of teachers knowledge and not sufficient to the preparation of teachers for the professional role of teaching. Darling-Hamond (1999) claims that this type of experience can socialize the pre-service teacher in to maintenance of status quo rather than developing critical inquiry approach in which teaching as a profession is underpinned by lifelong learning. Alongside with these principles, the Philippine Normal University, the National Center for Teacher Education of the country indulge its pre-service science teachers, specifically the biology pre-service teachers in an enhance curriculum that includes research- and laboratory-based on-the-job training cum practicum. Immersing the preservice biology teachers to research and laboratory-based on-the-job training enhanced and fully developed their process skills making them probable candidates of proficient 
science/biology teachers. They are not only proficient in teaching theories and practical knowledge in relation to pedagogy, assessment and classroom matters but also adept in the skills needed to effectively teach science investigation to the young and critical minds of Filipino learners. This program does not only target to improve pre-service science teachers, but eventually achieve scientific literacy leading to the end goal of sustainable development, lifelong learning of Filipinos. As aforementioned, OJT students find the OJT program good, effective if not very effective in their pre-service education.

Basically, OJT program assessment using Stufflebeam's (2007) CIPP model helped in identifying best practices of the OJT program featuring agency-university collaboration. Aside from distinguishing the benefits and advantages of the OJT program to the pre-service training of science students, other verbal comments served as inputs to policy developers. Future attempt to this study may include development of primer or handbook on program and implementation of research- and laboratory-based on-the-job training for pre-service science teachers. Comparative study on practicum cum research- and laboratory-based OJT may be sought for further expansion of literature in this field.

\section{References}

Carr, W. (2009). Practice without theory? A postmodern perspective on educational practice. In B. Green (Ed.), Understanding and researching professional practice. Rotterdam: Sense Publishers.

Church, C. H. (1988), "The qualities of validation”, Studies in Higher Education, 13, 27-43.

Darling-Hammond, L., and Berry, B. (1998). Investing in teaching: The dividend is student achievement. Education Week, Retrieved March 30, 2015 from http://w.teachingquality.org/pdfs/bb_cv.pdf

Darling-Hammond, L. (1999). Educating teachers for the next century: Rethinking practice and policy. In G. Griffin (Ed.), The education of teachers: 98th NSSE Yearbook, Part I (pp.221-256). Chicago: NSSE.

Eilertsen, T.V., Strøm, B. (2008).Towards a Symbiosis of Learning and Examinations in Teacher Education. In M. Mattsson, I. Johansson and B. Sandström, Examining Praxis: Assessment and Knowledge Construction in Teacher Education Rotterdam: Sense Publishers.

Eraut, M. (2006/1994). Developing professional knowledge and competence. London: Falmer Haugaløkken, O. K., Ramberg, P. (2005). NTNUs partnerskapsmodell: Et samarbeid mellom skole og laererutdanningsinstitusjon. Evaluering og analyse. Trondheim: NTNU.

Kemmis, S. (2009). Understanding professional practice: A synoptic framework. In B. Green (Ed.), Understanding and researching professional practice. Rotterdam: Sense Publishers.

Kvale, S. (red.) (2000). Mästarlära: lärande som social praxis. [Master knowledge: learning as social praxis] Lund: Studentlitteratur.

Lave, J. \& Wenger, E. (1991). Situated learning: legitimate peripheral participation. Cambridge: Cambridge Univ. Press.

Lindström, L. (2008). The Teacher as Servant of Nature. In M. Mattsson, I. Johansson and B. Sandström (Eds.) Examining Praxis: Assessment and Knowledge Construction in Teacher Education Rotterdam: Sense Publishers. 
Mattsson, M. (2008a). Degree Projects and Praxis Development. In M. Mattsson, I. Johansson and B. Sandström. (Eds.), Examining Praxis. Assessment and Knowledge Construction in Teacher Education Rotterdam: Sense Publishers.

Mattsson, M. (2008b). What is at Stake? In M. Mattsson, I. Johansson \& B. Sandström (Eds.), Examining Praxis. Assessment and Knowledge Construction in Teacher Education Rotterdam: Sense Publishers.

Mattsson, M., Eilertsen, T.V., \& Rorrison, D. (eds.). (2011). A Practicum Turn in Teacher Education. Rotterdam: Sense Publishers.

Ponte, P. (2007). Postgraduate education as platform. A conceptualisation. In J. van Swet, P. Ponte, \& B. Smit (Eds.), Postgraduate programmes as platform. A research-led approach. Rotterdam: Sense Publishers.

Rorrison, D. (2011). Border Crossing in Practicum Research. In A Practicum Turn in Teacher Education. Rotterdam: Sense Publishers.

Schulz, R. (2005). The practicum: More than practice. Canadian Journal of Education, 28(1/2), 147169.

Shulman, L. S. (1986b). Those who understand: Knowledge growth in teaching. Educational Researcher, 15(2), 4-14.

Stufflebeam, D. (2007). CIPP Evaluation Model Checklist, A tool for applying the CIPP Model to assess long-term enterprises: Evaluation Checklists Project. Retrieved March 15, 2013 from http://www.wmich.edu/evalctr/archive_checklists/cippchecklist_mar07.pdf

Van de Ven, P H (2011). Reflections from a Dutch Perspective. In M.Mattsson, T.V. Eilertsen \& D. Rorrison (Eds.), A Practicum Turn in Teacher Education. Rotterdam: Sense Publishers.

Wenger, E., McDermott, R. \& Snyder, W.M. (2002). Cultivating communities of practice: a guide to managing knowledge. Boston: Harvard Business School Press.

World Wide Learn. (2015, April 4) from http://www.worldwidelearn.com/

Position Paper on Education Post- 2015 (2014, August 15). Retrieved from UNESCO website:

http://en.unesco.org/post2015/.

Grand Canyon University. (2015, April 12) from http://www.gcu.edu/. (2013)

Philippine Quality Framework. (2015, April 10) Retrieved from PQF (2013) website:

http://www.gov.ph/2012/10/01/executive-order-no-83-s-2012/

On the Job Training Manual. (2014, November 4,) Retrieved from DOLE (Department of Labor and

Employment) website: http://ro6.dole.gov.ph/fndr/mis/files/OJT\%20MANUAL.pdf (2006)

CHED Memorandum No. 30, s. 2004. Retrieved April 10, 2015 from

http://www.dlsu.edu.ph/offices/iaa/downloads/iaa-cmo-no-30-series-2004.pdf

People Management Association of the Philippines (PMAP). (2015, March 30) from http://www.pmap.org.ph/. (2006)

ASEAN Economic Community. (2015, March 30) from

http://www.adbi.org/files/2013.10.25.wp440.asean.economic.community.progress.challenge. (2003). 